\title{
The Correlation between Spiritual Care Giving and Nurses' Competences at Critical Care Units
}

\author{
Muhammad Deri Ramadhan ${ }^{1}$, Destiya Dwi Pangestika ${ }^{2 *}$, Nurul Fatwati Fitriana ${ }^{2}$
}

\begin{abstract}
${ }^{1}$ Department of Medical Surgical Nursing, Nursing Faculty, Institut Kesehatan Rajawali, Bandung, Indonesia ${ }^{2}$ Department of Emergency and Critical Care Nursing, Health Sciences Faculty, Universitas Muhammadiyah Purwokerto, Purwokerto, Indonesia

*Corresponding email: pdestiyadwi@rocketmail.com
\end{abstract}

\section{ARTICLE INFO \\ HOW TO CITED: \\ Ramadhan, M.D., Pangestika, D.D., \& Fitriana, N.F.(2020). \\ The Correlation between Spiritual Care Giving and Nurses` Competences at Critical Care Units. Jurnal Pendidikan Keperawatan Indonesia. 6(2), p. 122-127}

DOI:

10.17509/jpki.v6i2.27057

\section{ARTICLE HISTORY:}

Received

August 05, 2020

Revised

November 25, 2020

Accepted

December 03, 2020

Published

December 15, 2020

\begin{abstract}
Patients' complex and critical conditions may influence humans to fulfill their basic daily needs. One of the nurses' main task is giving the nursing care based on the patients' daily needs including spiritual care. However, the critical care nurses sometimes only focused on the patients' physical needs, without paying more attentions to the spiritual care. Many factors may influence the nurses' competences in giving the spiritual care, including nurses' perceptions, involvements with the other health workers, spiritual care input as a part of nursing curriculum. Thus, it is greatly important to explore the relationship between spiritual care giving and nurses' competences in developing the spiritual care to the patients. This study aims to identify the correlation between spiritual care giving and nurses' competences at critical care units. This quantitative correlation research employed a cross sectional design. Seventy seven critical care nurses at the intensive care units participated in this research. Two research instruments consisting of Spiritual Care Giving Scale (SCGS) and Spiritual Care Competence Scale (SCCS) were used to collect the data. The data was then bivariately analyzed to reveal the nurses' perceptions on spiritual care. The research results showed that spiritual care giving and nurses' competences had a strong relationship $(\mathrm{r}=0.619)$. Each domain in spiritual care giving scale had a strong relationship with nurses' competences. It can be concluded that nurses' competences in spiritual care giving can affect on how they give spiritual care to the patients.
\end{abstract}

Keywords: Critical Care Nursing, Critical Care Unit, Spiritual Care

\begin{abstract}
ABSTRAK
Kondisi pasien kritis yang komplek dapat menganggu terpenuhinya kebutuhan dasar manusia. Fokus perawat dalam merawat pasien adalah dengan memberikan asuhan keperawatan yang berdasar pada kebutuhan dasar manusia dimana salah satu kebutuhan dasar manusia yang juga harus dipenuhi adalah kebutuhan spiritual. Namun, kenyataannya perawat dalam memberikan perawatan kepada pasien hanya berfokus kepada perawatan medis dan fisik saja, tanpa melakukan pendekatan secara spiritual. Beberapa faktor dapat mempengaruhi kompetensi perawat dalam memenuhi kebutuhan spiritual pasien seperti persepsi perawat, keterlibatan dengan multidisiplin lain, melibatkan materi spiritual dalam kurikulum keperawatan. Berdasarkan paparan di atas, maka penting untuk dilakukan kajian mengenai hubungan kompetensi perawat dengan pemberian perawatan spiritual. Jika hal tersebut sudah dapat diketahui, maka ruangan intensif akan lebih mudah dalam mengembangkan bentuk pemberian kebutuhan spiritual pada pasien. Penelitian ini bertujuan untuk mengetahui hubungan antara kompetensi perawat
\end{abstract}


dan pemberian perawatan spiritual pada perawat kritis. Jenis penelitian yang digunakan adalah penelitian kuantitatif korelasi dengan desain penelitian cross sectional. Responden pada penelitian ini adalah perawat yang bekerja di Unit Rawat Intensif sebanyak 77 orang. Instrumen penelitian yang digunakan adalah Spiritual Care Giving Scale (SCGS) dan Spiritual Care Competence Scale (SCCS). Pada penelitian ini, data dianalisis secara bivariat untuk mengetahui hubungan kompetensi perawat dan pemberian perawatan spiritual. Secara umum, pemberian perawatan spiritual mempunyai hubungan yang kuat dengan kompetensi perawat $(r=0.619)$ dimana setiap domain dalam Spiritual Care Giving Scale (SCGS) mempunyai hubungan yang kuat (p value $<0.00)$ dengan kompetensi perawat dalam memberikan perawatan spiritual. Hasil analisa tersebut dapat disimpulkan bahwa kompetensi perawat tentang perawatan spiritual dapat mempengaruhi bagaimana pemberian perawatan spiritual kepada pasien. Penelitian selanjutnya diharapkan dapat melakukan intervensi berupa pelatihan pemberian perawatan spiritual untuk perawat agar dapat diaplikasikan di rumah sakit.

Kata kunci : Keperawatan Kritis, Spritual, Unit Perawatan Intensif

\section{INTRODUCTION}

Critical ill patients have a high dependency on their negative feelings, such as helplessness (Yang, 2016). In addition, most patients at critical care units feel greatly stressful and uncomfortable (Willemse et al., 2020). They did not only need physical but also psychological or emotional therapies, such as spiritual therapy (Choi et al., 2015). Carr (2018) explained that spiritual sense or value is in line with compassion, generosity, gratitude and forgiveness as well as theological virtue of faith, hope, and charity. The American Association of Nursing Colleges declared that spiritual care is not an optional but nurses' responsibility. However, nurses only focus on medical treatments and physical needs, without considering the spiritual care. This condition was supported by the result of research conducted by Abuatiq (2015) mentioned that critical care nurses only focus more on physical improvements, such as oxygenation, perfusion, and nutrition than spiritual needed. Many factors may influence the nurses in fulfilling the patients' spiritual needs, such as nurses' perceptions. It was supported by Ozbasaran et al., (2011) said that nurses' perceptions on spiritual aspect may become one obstacle in giving the spiritual care. Furthermore, nurses' perceptions may also influence how they behave, take care, and communicate with the patients (Sianturi, 2015). Chan (2010) similarly explained that nurses' perceptions may influence their competences in giving the spiritual care. In addition, Azarsa et al. (2015) said that nurses' spiritual competence is related to their spiritual levels. Thus, the researchers are interested in identifying the relationship between spiritual care giving and nurses' competences.

\section{METHODS}

\section{Population and samples}

This quantitative correlational study used cross sectional design with total sampling technique. The research population included nurses at critical care unit. 77 nurses were participated in this study. The inclusion criteria were nurses at critical care units for 2 years (minimum duration of work), nurses' education are diploma and bachelor, and never get spiritual training. Meanwhile, the nurses whose are paid leave and have spiritual training were excluded in this research. Data were statistically analyzed by using Spearman Correlation Coefficient.

\section{Location and Time}

This research was conducted at critical care unit at Hospital type A consisting of ICU (Intensive Care Unit), ICCU (Intensive Cardiac Care Unit), PICU (Pediatric Intensive Care Unit), and $\mathrm{HCU}$ (High Care Unit) in April 2020.

\section{Research Instruments}

This research used two questionnaires consisting of Spiritual Care Giving Scale (SCGS) and Spiritual Care Competence Scale (SCCS). The SCGS questionnaire included 35 questions with six answer levels (strongly disagree, disagree, 
Ramadhan, M.D., Pangestika, D.D., \& Fitriana, N.F.| The Correlation between Spiritual Care Giving and Nurses `...

somewhat disagree, somewhat agree, agree, strongly agree). The minimum score of SCGS is 35 while the maximum score is 210 . The SCGS questionnaires were distributed to reveal the nurses' perceptions on the importance of spiritual needs and how to fulfill the patients' spiritual needs. Meanwhile, the SCCS questionnaire consists of 27 questions with six divided domains (attitude toward the patients' spirituality, communication, spiritual care assessment and implementation, referral, personal support and patient counseling, professionalism and spiritual care quality improvement. The minimum score of SCCS is 27 while the maximum score is 135 . The answer categories consisted of $1=$ strongly disagree; $2=$ disagree; $3=$ neutral; $4=$ agree; $5=$ strongly agree. Both questionnaire used likert scale and interpreted by numeric scale, higher scores indicate a higher level of competences and care giving.

Spiritual Care-Giving Scale (SCGS) has indonesian version which was validity tested with CVI (Content Validity Index) $>0,8$ at 35 questions. Then, validity construct was tested in 30 nurses in hospital $(r=0,427-0,882>r$ table $(0,361)$ that conclude all of questions in SCGS is valid. Meanwhile, reliability test was tested with cronbach alpha $0.97(>0,60)$ which means SCGS is reliable (Purwatisari, 2015). Spiritual Care Competence Scale has also been tested for validity and reliability in 27 items, test of validity used Pearson-product moment with significance of 0.05 . It showed the correlation value from the 27 items was valid $(\geq 0.2)$. It was reliable showed by the Cronbach's Alpha coefficient value of 0,694 for 27 items (Anisa, Erika, \& Rachmawaty, 2018)

\section{Ethics}

This research has been approved by the Ethics Commission of Prof. Dr. Margono Soekardjo Hospital Number 420/00172/XII/2019.

\section{RESULT}

Table 1 shows that the most of respondents were aged $31-40$ years old $(48.1 \%)$, have been working for more than 10 years $(40,3 \%)$, and graduated from the associate degree (53.2\%).
Table 1. Distribution of Respondents Characteristics at ICU, ICCU, PICU, and HCU (n=77)

\begin{tabular}{lll}
\hline \multicolumn{1}{c}{ Characteristics } & \multicolumn{2}{c}{ Total } \\
\cline { 2 - 3 } Age (years old) & F & \% \\
20-30 & 27 & 35.1 \\
$31-40$ & 37 & 48.1 \\
$41-50$ & 11 & 14.2 \\
$51-60$ & 2 & 2.6 \\
Years of Service & & \\
0-5 years & 25 & 32.5 \\
6-10 years & 21 & 27.3 \\
>10 years & 31 & 40.2 \\
Religion & & \\
Islam & 76 & 98.7 \\
Catholic & 1 & 1.3 \\
Education & & \\
Associate Degree & 41 & 53.2 \\
Bachelor Degree & 1 & 1.3 \\
Nurse Profession & 35 & 45.5 \\
Position & & \\
Primary Nurse & 10 & 13.0 \\
Associate Nurse & 67 & 87.0 \\
Unit & & \\
ICU & 24 & 31.1 \\
ICCU & 15 & 19.5 \\
PICU & 10 & 13.0 \\
HCU & 28 & 36.4 \\
\hline
\end{tabular}

Table 2 shows that respondents' SCGS mean score is 163.49 with deviation standard 13.84. Meanwhile, respondents' SCCS mean score is 104.36 with deviation standard 9.633.

Table 2. Distribution of Spiritual Care Competence Scale (SCCS) Score and Spiritual Care Giving Scale (SCGS) Score

\begin{tabular}{lcc}
\hline \multicolumn{1}{c}{ Variables } & Mean \pm SD & Min-Max \\
\hline Spiritual Care Competence & $104.36 \pm 9.633$ & $85-128$ \\
$\begin{array}{l}\text { Scale (SCCS) } \\
\text { Spiritual Care Giving Scale } \\
\text { (SCGS) }\end{array}$ & $163.49 \pm 13.84$ & $132-198$ \\
\hline
\end{tabular}

Table 3 shows that each domain in the Spiritual Care Giving Scale (SCGS) had a strong relationship with the Spiritual Care Competence Scale (SCCS) with the $p$ value of $<0.001$. The Correlation analysis used the Spearman correlation coefficient with the attribute $r=0.647$, perspective at $\mathrm{r}=0.414$, definition at $\mathrm{r}=0.532$, attitude at $\mathrm{r}=$ 0.568 , and value at $\mathrm{r}=0.573$. 
Ramadhan, M.D., Pangestika, D.D., \& Fitriana, N.F.| The Correlation between Spiritual Care Giving and Nurses ` ...

Table 3. Correlation between Spiritual Care Competence Scale (SCCS) and Spiritual Care Giving Scale (SCGS) $(\mathrm{n}=77)$

\begin{tabular}{ccc}
\hline \multirow{2}{*}{ Variables } & \multicolumn{2}{c}{ Spiritual Care Competence Scale } \\
\cline { 2 - 3 } & $\mathbf{r}$ table & p-value \\
\hline Spiritual Care Giving & $0.619^{* *}$ & \\
Attribute & $0.647^{* *}$ & \\
Perspective & $0.414^{* *}$ & $<0.001$ \\
Definition & $0.532^{* *}$ & \\
Attitude & $0.568^{* *}$ & \\
\hline Value & $\mathbf{0 . 5 7 3 * *}$ & \\
\hline
\end{tabular}

\section{DISCUSSION}

The result of study found overall respondents had high score of spiritual care giving scale $(163.49 \pm 13.84)$ and high score of spiritual care competence $(104.36 \pm 9.633)$. It might be affected by some factors such as common belief/ religious similarity between nurses and patients. This recent study shows majority nurses are Islam $(98,7 \%)$ where majority patients and Indonesian Society are Islam. This similarity belief will make it easier for nurses to support the spiritual needs of patients (Azarsa et al., 2015). Another factor that can also influence the results of this study is the length of work, where some nurses have a service period of $>10$ years by $40.2 \%$. The length of the working period is related to the nurse's ability to provide comprehensive nursing care (Melhem et al., 2016).

This research generally shows that nurses' competences and spiritual care giving has a strong relationship $(\mathrm{p}<0.001)$. The result of this research was supported by Azarsa et al., (2015) stated that nurses' spiritual competence had a strong relationship with the nurses' spiritual level. Spiritual care is a dynamic concept describing a unique integrity aspect of giving care to the patients (Ramezani et al., 2014). A literature review provided Visser et al. (2010) showed that spirituality had a strong relationship with higher wellbeing. Spiritual practice and religion may help reduce the physical and mental health problems as well as the mortality rate.

The Spiritual Care Giving Scale (SCGS) consists of some domains which each has a strong relationship with the nurses' competences. The first domain, attribute, consists of the professional health workers' involvements in spiritual care giving, patients' perceptions on spiritual aspect, nurses' spiritual needs fulfillment, professional institutions' religious involvements, and nursing education curriculum. The spiritual care giving concerns more on the aspects which possibly increase the nurses' competences. This statement is relevant with the research conducted by Hamid (2015) showing that the nurses' adequate spiritual needs might influence the spiritual care giving quality. Furthermore, a research conducted by Azarsa et al., (2015) also said that the spiritual level of nurses working at the critical care units had a strong relationship with the spiritual care giving or in other words, the nurses with high spiritual level might provide the patients more optimum spiritual care giving. The other aspect in attribute domain is spiritual as a part of curriculum in nursing education. Melhem et al., (2016) supported this research as mentioning that education might increase the spiritual care competence. In this study, most of the nurses have associate degree (41 nurses) which can relate to their performance in spiritual care to the patients. Most respondents think that giving spiritual care just for patients with poor condition or almost dead.

The next domain contained in the SCGS is perspective which has a strong relationship with nurses' competences. Chan (2010) said that the nurses' perceptions on spiritual aspect and spiritual care might influence their care giving competences. Besides, the literature review provided by Kalish (2012) showed that the health workers' spiritual level might influence their spiritual care giving to the patients. Baird (2016) also found that Moslem nurses in Jordania did not regularly provide the spiritual care giving. The results of this research showed that nurses' perceptions had a strong relationship with nurses' competences. It was also supported by the research conducted by the Royal College of Nursing (2011) on 4000 nurses. Most of them said that spirituality is one important element in nursing care giving to increase the care giving quality. Furthermore, the Royal College of Nursing found that $95.5 \%$ nurses provided the spiritual care giving to the patients 
and $41.4 \%$ nurses also provided the spiritual care giving in the patients' daily needs.

Spirituality has an important role in critical nursing. Nurses in critical areas must provide optimal care in patients' spiritual needs. Herman (2006) stated that spirituality is a patient's simple desire to find purpose and meaning in life. Patients with critical condition need spiritual care, fearness will present related to the healthy change status. It can cause the patient isolate themselves from the environment. Spiritual care emphasizes transcendence and enhances connections to support the family and patient thereby helping with healing and recovery.

\section{CONCLUSION}

Spiritual care giving and nurses' competences has a strong relationship. Each

\section{REFERENCES}

Abuatiq, A. (2015). Spiritual Care for Critical Care Patients. International Journal of Nursing \& Clinical Practices, 2(1), 2-5. https://doi.org/ 10.15344/2394-4978/2015/128

Anisa, N. R., Erika, K. A., \& Rachmawaty, R. (2018). Nurse's Spiritual Care Competencies to Patient with End Stage Breast Cancer. International Journal of Public Health Science (IJPHS), 7(4), 268. https://doi.org/10.11591/ijphs.v7i4.14742

Azarsa, T., Davoodi, A., Khorami Markani, A., Gahramanian, A., \& Vargaeei, A. (2015). Spiritual wellbeing, Attitude toward Spiritual Care and its Relationship with Spiritual Care Competence among Critical Care Nurses. Journal of Caring Sciences, 4(4), 309-320. https://doi.org/10.15171/ jcs. 2015.031

Baird, Pamela. (2016). Spiritual care intervention in Spiritual, Religious, and Cultural Aspects of Care. Oxford: Oxford University Press, pp. 29-45.

Carr, D. (2018). Spirituality, spiritual sensibility and human growth. International Journal domain in spiritual care giving scale (SCGS) has a strong relationship with the nurses' competences. The results from this research found that the relationship between nurses' perceptions, spiritual care understanding, and spiritual care giving can motivate the nurses to give the best spiritual care, increase self-spiritual awareness, and selfreflection. Thus, the nurses may closely engage with God, environment, and patients. In addition, based on the study result, spiritual care competence should be included to the nursing curriculum.

\section{ACKNOWLEDGEMENT}

The authors highly appreciate the Research and Community Service Department of Universitas Muhammadiyah Purwokerto for supporting this research by funding and reviewing this research.

for Philosophy of Religion, 83(3), 245-260. https://doi.org/10.1007/s11153-017-9638-x

Chan, M. F. (2010). Factors affecting nursing staff in practising spiritual care. Journal of Clinical Nursing, 19(15-16), 2128-2136. https://doi.org/10.1111/j.1365-2702.2008. 02690.x

Choi, P. J., Curlin, F. A., \& Cox, C. E. (2015). "The Patient Is Dying, Please Call the Chaplain": The Activities of Chaplains in One Medical Center's Intensive Care Units. Journal of Pain and Symptom Management, 50(4), 501-506. https://doi.org/10.1016/j. jpainsymman.2015.05.003

Hamid N, Dehghanizadeh Z. (2015). The relationship between spirituality, Predictors of spiritual care competence among nurses Journal of Caring Sciences, December 2015; 4 (4), 309-320|319

Kalish, N. (2012). Evidence-based spiritual care: A literature review. Current Opinion in Supportive and Palliative Care, 6(2), 242$246 . \quad$ https://doi.org/10.1097/SPC. 0b013e328353811c

Melhem, G. A. B., Zeilani, R. S., Zaqqout, O. Abed., Aljwad, A. I., Shawagfeh, M. Q., \& 
Ramadhan, M.D., Pangestika, D.D., \& Fitriana, N.F.| The Correlation between Spiritual Care Giving and Nurses ` ...

Al- Rahim, M. A. (2016). Nurses' Perceptions of Spirituality and Spiritual Care Giving: A Comparison Study Among All Health Care Sectors in Jordan. Indian Journal of Palliative Care, 22(1), 42-49. https://doi.org/10.4103/0973-1075.173949

Ozbasaran, F., Ergul, S., Temel, A. B., Aslan, G. G., \& Coban, A. (2011). Turkish nurses' perceptions of spirituality and spiritual care. Journal of Clinical Nursing, 20(21-22), 3102-3110. https://doi.org/10.1111/j.13652702.2011.03778.x

Purwatisari. (2015). Gambaran Persepsi Perawat Mengenai Kebutuhan Spiritual dan Pemenuhan Kebutuhan Spiritual Pasien Kanker di RSUD Tugurejo Semarang. Universitas Diponegoro. (cited on November 23, 2020), retrieved from https://eprints.undip.ac.id

Ramezani, M., Ahmadi, F., Mohammadi, E., \& Kazemnejad, A. (2014). Spiritual care in nursing: A concept analysis. International Nursing Review, 61(2), 211-219. https://doi.org/10.1111/inr.12099

Royal College of Nursing. (2011). $R C N$ Spirituality Survey 2010. London: Royal College of Nursing
Sary, Selly Puspita. (2018). Hubungan Kecerdasan Spiritual Perawat dengan Pemenuhan Kebutuhan Spiritual Pasien. (cited on November 23, 2020) retrieved from http://repository.unej.ac.id/handle/1234567 $89 / 87350$

Sianturi, N. J. (2015). Persepsi Perawat dan Manajer Perawat tentang Spiritual Care di RSUD Dr R.M. Djoelham Binjai. http://repository.usu.ac.id/handle/12345678 9/44553

Visser, A., Garssen, B., \& Vingerhoets, A. (2010). Spirituality and well-being in cancer patients: A review. Psycho-Oncology, 19(6), 565-572. https://doi.org/10.1002/pon.1626

Willemse, S., Smeets, W., van Leeuwen, E., Nielen-Rosier, T., Janssen, L., \& Foudraine, N. (2020). Spiritual care in the intensive care unit: An integrative literature research. Journal of Critical Care, 57, 55-78. https://doi.org/10.1016/j.jcrc.2020.01.026

Yang, R. (2016). Dependency in Critically Ill Patients: A Meta-Synthesis. Global Qualitative Nursing Research, 3, 233339361663167. https://doi.org/10.1177/ 23333936166316778. 